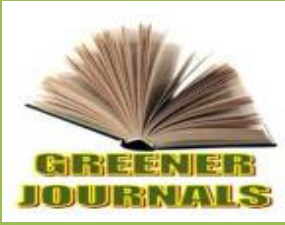

Research Article

\title{
Public Investment in the Social Sector and Employment Generation in Nigeria, 1980-2016
}

\section{Daniel CHARLES ${ }^{*}$, Simeon G. NENBEE (PhD) and Itode J. KRAMA (PhD)}

Department of Economics, Faculty of Social Sciences, University of Port Harcourt, Port Harcourt, Nigeria.

Article No.: 122617182

DOI: 10.15580/GJSS.2018.1.122617182

Submitted: $26 / 12 / 2017$

Accepted: 04/01/2018

Published: 16/01/2018

${ }^{\star}$ Corresponding Author

Daniel Charles

E-mail: charlesdan2014@yahoo .com

\section{Keywords:}

Public Investment, Social Sector,

Public Expenditure on Education,

Public Expenditure on Health,

Public Expenditure on Community

Services, and Employment

Generation.
The objective of this paper is to empirically examine the effect of public investment in the social sector on employment generation in Nigeria between 1980 and 2016. Time series data were sourced from secondary sources on unemployment rate (UNE) a proxy for employment generation, Government Expenditure on Education (EDU), Government expenditure on Health (HTH) and Government on Other Social and Community Services (COM). The data sets were analyzed based on the Dynamic OLS proposed by Stock-Watson (1993) technique of analysis to estimate the model. The result of the analysis reveals that Government Expenditure on Education (EDU) is rightly signed and is statistically significant while Government Expenditure on Health (HTH) and Government Expenditure on Other Social and Community services (COM) were wrongly signed and are statistically significant at 5 percent level. This implies that Government Expenditure on Health (HTH) and Government Expenditure on Other Social and Community services (COM) have not generated employment in Nigeria within the period under review. Based on these findings, the study recommends that government should encourage the education and health sectors through increased funding, as well as ensuring that the resources are properly managed and used for the development of education and health services. Lastly, government should increase its funding of anti-graft or anti-corruption agencies like the Economic and Financial Crime Commission (EFCC), and the Independent Corrupt Practices Commission (ICPC) in order to arrest and penalize those who divert and embezzle public funds. 


\section{INTRODUCTION}

Public investment is government acquisition of capital goods and services, tangible and intangible assets, stocks, non-financial assets, etc, not for immediate consumption but for further production of final goods and services in the future. The social sector is the segment of society responsible for the building, processing and development of human resources and it can be classified into education, health and community service. Investments in Education and Health (Human Capital) have long been identified as a driving force for the growth of an economy. Harbison (1973) rightly expressed that "human resources constitute the ultimate basis of production; human beings are the active agents who accumulate capital, exploit natural resources, build social, economic and political organizations; and carry forward national development. Clearly, a country which is unable to develop the skills and knowledge of its people and utilize them effectively in the national economy will be unable to develop anything else."

Several empirical studies have established the positive relationship between investment in human capital and economic growth. Prominent amongst these are the studies of Denison (1983), Schultz (1961), Solow (1957) and more recently Khilji (2005), Babatunde and Adefabi (2005), Lawal and Wabab (2011), and Saima et al (2012). In recognition of the importance of investment in social services (Education and Health), countries of the world (both developing and developed countries) have invested in the social sector so as to reap the benefits associated with it. Fagerlind and Saha (1997), Duada (2010) and Olayemi (2012) gave justification for large public expenditure on health and education services.

Economists have been occupied with public spending on human capital- growth nexus as there is no study that have explicitly examined the nexus between public investment in the social sector and job creation (unemployment reduction). The channel of improved education and health care services enhancing productivity of the labour force which translates to economic growth has been the centre of debate amongst economists. It is important to state that growth is achievable in an economy with the use of laboursaving technologies, thus an economy can experience growth without necessarily providing increased job opportunities. Therefore, this study intends to incorporate employment generation in the link between public investment in human capital and growth nexus.

Aside the introductory section, this paper is subdivided into literature review, method of study, presentation of results and findings and finally conclusion and recommendation.

\section{LITERATURE REVIEW}

\subsection{Theoretical Review}

Economics literature is replete with several theories on public expenditure but for brevity, Wagner's law of increasing state activities, Peacock-Wiseman theory and Rostow-Musgrave theory are reviewed

\section{Wagner's Law of Increasing State Activities}

Wagner's law of increasing state activities states that there are inherent tendencies for the activities of government sector to increase in industrializing economies. Adolph Wagner (1835-1917), the nineteenth century German statistician, was concerned with both the absolute and relative growth share of the Gross National Product (GNP) consumed by the public sector. Specifically, Wagner observed that, as per capita income in an economy grows, the relative size of the public sector grows also, and that government expenditure would inevitably increase at a faster rate than national output.

Wagner explained why he had observed the emergence of public sector service such as legal service, policy service and banking service. The growth of public expenditure on education, recreation, culture, health and welfare services were explained in terms of their income elasticities of demand (Ogwuru, 2008). It shows that economic development requires a rising share of the public sector service where superior commodities attract faster demand as real income rises.

According to Agiobenebo (2000), Wagner had a perspective vision of the consequences of industrial development. He recognized that as industrialization develops, markets and contracts would grow with it, thus the nature of economic, social, political and institutional relationships would grow increasingly complex. The increased complexity of market interactions arising from this process would result in the need for increased commercial laws and contracts which in turn will require system of regulation and justice to enforce them.

\section{Peacock-Wiseman's Theory}

The period 1890-1955 witnessed a second thesis on the growth trend of public investment as Peacock-Wiseman provides another variant to the debate. Their main emphasis is that public expenditure does not increase in a smooth and continuous manner, but in a step by step fashion.

Both government and the people now agree to the required adjustments in financing the increased expenditure.

What Peacock-Wiseman succeeded in doing was the identification of scenarios that give rise to periodic jumps in public expenditure and thereby provided explanation for one of the attributes of public expenditure towards its long run level. It is equally important to note that apart from various factors like population growth, defense expenditure, urbanization, rising prices and among others, which by themselves 
were pushing the public expenditure up, the failure of the market mechanism to let the economy achieve its various objectives, efficiently has made inevitable for government to expand its activities and has to a corresponding increase in public expenditure (Musgrave and Musgrave, 1989).

\section{The Rostow-Musgrave Development Model}

Rostow (1967) presented a political theory of the stages of growth and the role of public finance in the process, whereas, Musgrave (1979) provide a macroeconomic view point of public expenditure policy for industrialization and development. According to the model in early stages of economic growth and development public sector investment as a proportion of total investment is found to be high. The public sector is therefore seen to provide social overhead capital in the form of real (roads, bridges, air-and-sea-ports, communication system utilities and transport) and human capital in the form of expenditure on education, health and nutrition, etc. this public investment, it is argued, is necessary to gear up the economy into the middle stages of socio-economic development.

In the middle stages, government continues to supply investment goods, which are thought to be complementary to private investment. But, it is difficult to see what time public investment in social overhead capital cease not be complementary to private investment.

In anyway, during all stages and phases of development, market failures occur and call for an expanding scope of government activity. Hence, Musgrave argues that, over the development period, as total investment as a proportion of Gross National Product (GNP) rises, the relative share of the public sector investment falls, but not absolutely. Whereas Rostow claims that once the economy reaches the mature stages, the mix of public expenditures will shift from expenditures on infrastructures to increasing expenditure on education, health and welfare services.

From the foregoing, one may ask the question of the stage that Nigeria is presently. Nigeria cannot be classified easily into any of the three stages suggested by Rostow and Musgrave because over the years government investment; both real and human capital have been massive. Again, the ratio of public investment to total investment has also remained high in the country. Regardless of the current stage of the country, public investment in the social sector is expected to launch the economy on the path of development.

\subsection{Review of Empirical Literature}

Very few studies have examined the relationship between public expenditure on the social sector and employment generation in a single study. For instance; Ogunrinola (2010) studied informal self-employment and poverty alleviation covering two major cities in Nigeria and concluded that informal sector is a high employer of young school leavers and it further confirmed that some graduates of tertiary institutions are also found in the informal sector taking up the job of auto-cycle riding due to lack of desired formal sector employment.

Sodipe and Ogunrinola (2011) investigated the employment and economic growth relationships in the Nigerian economy adopting a simple model and using the ordinary least square technique, showed a positive and statistically significant relationship between employment level and economic growth in Nigeria while a negative relationship was observed between employment growth rate and GDP growth rate in the economy. Thus, the study recommends increased labour-promoting investment strategies that will help reduce high current open unemployment in Nigeria.

Fasanya and Onakoya (2012) examined the impact of informal sector on employment generation in Nigeria during the period 1970 to 2010. Adopting the Augmented Solow growth analytical framework, the study showed that informal sector activities have significant impact on absorbing the large pool of labour force in Nigeria. Thus, the researchers contend that human capital formation is positively related to unemployment which reflects the dearth of government expenditure on education in the country. Therefore, there is an urgent need for the government to reexamine its policies on informal sector.

In an attempt to determine the extent to which various employment generation programmes of the government had proved effective for achieving full employment in Nigeria, Mbah and Agu (2013) evaluated the effectiveness of government policies in Nigeria using data extracted from the Central Bank of Nigeria statistical bulletin and National Bureau of Statistics bulletin and adjusted for seasonal variation, trends and random factors, the study showed that employment policies of successive governments were not yet adapted to full employment and recommended that increased labour-promoting employment generation strategy can be pursued so as to create more jobs that can help reduce current open unemployment in Nigeria.

Adediran (2014) investigated a regime shift analysis between public investment in human capital and economic growth in Nigeria for the period 1961 to 2012. Adopting unit root test, cointegration and Error Correction model, the study established positive relationship between federal and state governments' spending on human capital (Education and Health) and economic growth. Finally, the study recommends the reintroduction of development planning in the current democratic dispensation and the resuscitation of agriculture in boosting the economy, generate foreign exchange, build foreign reserves, amongst others.

Kareem (2015) examine the link between employment level and the economic growth of Nigeria. The study adopted Ordinary Least Squares (OLS) method of regression analysis and causality tests to estimate the model. The results of the analysis shows that foreign direct investment, inflation, interest rate have positive relationship with Employment level (Y).The 
result of granger causality also shows that GDP granger cause Inflation at 1 percent level of significant, FDI Granger cause GDP with a percent level significant, Interest rate Granger cause GDP at 10 percent level of significant, FDI Granger cause Interest rate with a 10 percent level of significant. The result concluded that Gross domestic product (GDP), interest rate were factors that contributed to those Employment level in Nigeria. Based on the result, the study recommended that government should evolve appropriate economic policy so as to reduce the policies associated with interest rate and low output production (GDP).

Okafor and Kenneth (2016) studied whether public spending has induced employment opportunities in Nigeria. The study revealed that deficit financing of recurrent expenditure was a most important single factor inhibiting public spending from inducing economic growth for employment generation. It was recommended, inter alia, that to ensure its efficiency, tax policy, pricing policy, exchange - rate policy and credit policy should form integral components of a country's employment policy.

Elekwa, Aniebo and Ogu (2016) investigated the relationship between foreign portfolio investment and employment growth in Nigeria from 1980 to 2014 by using the Ordinary Least Squares (OLS) method of analysis. The study found that in the long term, portfolio investment impacts employment growth positively and significantly in Nigeria. This outcome supports the general view in the literature of a positive relationship between portfolio investment and economic growth, and calls attention to this variable which has hardly been considered in employment generation constructs on account of its famed volatility and risk. The study recommends that closer efforts to develop the portfolioflow climate should be established in Nigeria especially the cultivation of equity-end portfolio flow and stable foreign exchange regime.

Ekpenyong, Edem, and Ndiyo (2016) investigate the role of public and private sectors in tourism development in Nigeria, with particular reference to Cross River State. A total of 300 respondents were sampled using stratified random sampling technique. The study used the descriptive statistics such as simple tables, frequencies, and percentages. The result of the analysis reveals that both the public and private sectors have contributed differently to the development of tourism in Cross River State. Specifically, the results showed that the public sector has contributed to tourism development by developing tourism sites, providing good roads to tourism sites, providing electricity to tourism sites, providing adequate security to tourists, providing tour guards and creating enabling environment for tourism business to thrive in the state, constructing and operating hotel services, granting scholarship for tourism study, developing tourism site, providing adequate security to tourists, providing transport services and tour guides. Based on the results, the study recommended that government should continue to do more to promote tourism sector in Cross River State. The government can do this by increasing its financing of the sector; providing adequate security to tourists, and providing adequate infrastructures such as steady electricity supply to tourism sites.

Ajakaiye, Afeikhena, David and Olufunke (2016) examine the relationship between growth and employment in Nigeria to gain insights into the country's paradox of high economic growth alongside rising poverty and inequality. The study employed the World Bank stepwise decomposition approach using the Shapley decomposition method (World Bank 2010) to estimate the model. The findings indicate that Nigeria's growth over the last decade has been 'jobless' and sustained largely by factor reallocations rather than productivity enhancement. Labour reallocations have been mainly from agriculture and manufacturing towards the low productive services sector. Employment elasticity of growth was positive and quite low, reflecting the country's poor overall employment generation record, especially in manufacturing.

Apata, Sanusi, Obaisi and Ajani (2016) analyzed the relationship between public spending and agricultural growth in Nigeria and Malaysia from 1970 to 2010 and employed the panel data analysis. The study reveals that government expenditure indeed has a significant influence on economic growth in the long run as demonstrated in Nigeria and Malaysia. Therefore, government expenditure is a crucial component of fiscal policy to achieve economic objectives. However, if government expenditure patterns are not well designed to fit the economy's needs it could significantly influence the economy in a negative way and the society bears the costs.

Adebayo and Ayegbusi (2017) studied publicprivate partnership as a mechanism for employment creation in Nigeria. The study found that public-private partnership is the best measure to create employment opportunity and to save the Nigeria from monoculture economy system to diversified economy. The study therefore suggest government should tap the resources available in the socio-political zones to create jobs as well as vibrant economic policies and stable political climate which be put in place to enhance effective partnership between public and private sectors for employment creation.

\subsection{Summary of literature reviewed and research gap}

From the literature review, it was observed the only few studies exist on the relationship between public expenditure on the social sector and employment generation. Most of the studies were concerned on the relationship between public expenditure and agriculture or on economic growth, etc. Others looked at agricultural development and employment generation, Public-Private Partnership as Mechanism for Employment Creation, expenditure on education, health and transport and communication had insignificant effect on economic growth, foreign direct investment and foreign portfolio investment and employment generation, etc. But this 
study focuses on the effect of public expenditure on social sector on employment generation in Nigeria between 1980 and 2016 by using the Dynamic Ordinary Least Squares (DOLS) proposed by Stock and Watson (1993) to estimate the model.

\section{THE METHOD SPECIFICATION}

The data used for this study were obtained from various sources, the Central Bank of Nigeria (CBN) Statistical Bulletin (various issues) and other database documents of institution via the internet. The data set covered four variables; Employment proxy by unemployment Rate (UNE), Government Expenditure on Education (EDU), Government Expenditure on Health (HTH) and Government Expenditure on Other Social and Community Services (COM). Both descriptive statistics and Stock-Watson Dynamic Ordinary Least Square (DOLS) method of analysis are employed to estimate the model parameters.
The method DOLS was adopted because it improves on the classical (ordinary) least squares (OLS) by coping with small sample and dynamic sources of bais. It is a robust single equation approach which corrects for regressor endogeneity (peculiar with cointegrating relationships) by the inclusion of leads and lags of the first differences of the regressors, and for serially correlated errors (residuals) by a generalized least squares (GLS) procedure to provide optimal estimates of cointegrating regressions (Al-Azzam and Hawdon, 1999 and Oaikhenan and Aigheyisi, 2015).

The analytical framework for this study follows the works of Obayori (2016) on the impact of Government Expenditure in the social sector on employment generation in Nigeria but with slight modification. This study in contrast to Obayori (2016) concentrates on the social sector by regressing unemployment as a function of Government Expenditure on Education (EDU), Government Expenditure on Health $(\mathrm{HTH})$ and Government Expenditure on Other Social and Community Services (COM).

Thus, the functional relationship between the dependent and the explanatory variables is stated as follows:

$\mathrm{UNE}=f(E D U, H T H, C O M)$

UNE = unemployment a proxy for employment generation

$\mathrm{EDU}=$ Government Expenditure on Education

$\mathrm{HTH}=$ Government Expenditure on Health

$\mathrm{COM}=$ Government Expenditure on Other Social and Community Services

Accordingly, the econometric of the model is stated as follows:

$\mathrm{UNE}_{t}=\beta_{0}+\beta_{1} \mathrm{EDU}_{t}+\beta_{2} \mathrm{HTH}_{\mathrm{t}}+\beta_{3} \mathrm{COM}_{\mathrm{t}}+\mathrm{U}_{\mathrm{t}}$

$\mathrm{UNE}_{\mathrm{t}}=$ unemployment a proxy for employment generation at time " $\mathrm{t}$ "

$\mathrm{EDU}_{\mathrm{t}}=$ Government Expenditure on Education at time "t"

$\mathrm{HTH}_{\mathrm{t}}=$ Government Expenditure on Health at time "t"

$\mathrm{COM}_{\mathrm{t}}=$ Government Expenditure on Other Social and Community Services at time " $\mathrm{t}$ "

$\beta_{i}=$ Parameter estimates

$\mu_{\mathrm{t}}=$ Error term

The apriori signs are stated as follows:

$\beta_{1}, \beta_{2}$ and $\beta_{3}>0$

\section{RESULTS AND DISCUSSION}

\subsection{Descriptive statistics}

Table 1 presents the summaries of the descriptive statistics for the variables used in this study. It shows the mean, medium, maximum, minimum and standard deviation values etc. 
Table 1: Descriptive Statistics

\begin{tabular}{lcccc}
\hline & UNE & EDU & HTH & COM \\
\hline Mean & 10.99722 & 84013.00 & 46774.28 & 51335.11 \\
Median & 8.700000 & 14221.52 & 4316.685 & 3212.580 \\
Maximum & 27.40000 & 390424.9 & 231800.0 & 281000.0 \\
Minimum & 3.200000 & 162.1500 & 41.31000 & 31.21000 \\
Std. Dev. & 6.031938 & 120750.4 & 70160.42 & 92805.90 \\
Skewness & 1.184817 & 1.473405 & 1.491341 & 1.631570 \\
Kurtosis & 3.681471 & 3.818415 & 3.873662 & 3.910958 \\
Jarque-Bera & 9.119349 & 14.03024 & 14.48952 & 17.21688 \\
Probability & 0.010465 & 0.000898 & 0.000714 & 0.000183 \\
Sum & 395.9000 & 3024468. & 1683874. & 1848064. \\
Sum Sq. Dev. & 1273.450 & $5.10 \mathrm{E}+11$ & $1.72 \mathrm{E}+11$ & $3.01 \mathrm{E}+11$ \\
Observations & 36 & 36 & 36 & 36 \\
\hline
\end{tabular}

Source: Authors' Computation (2017)

The result of the descriptive statistics in Table 1 shows that the mean values of the variables - UNE, EDU, HTH and COM are 10.997, 84013.00, 46774.28 and 51335.11 respectively. The table also shows that the maximum values of each of the variables are 27.40 UNE, 390424.9 for EDU, 231800.0 for HTH and 281000.0 for COM, respectively while the minimum values are 3.2 for UNE, 162.15 for EDU, 41.31 for HTH and 31.21 for COM, respectively. It further shows that the standard deviations in each of the variables are 6.03 for UNE, 120750.4 for EDU, 70160.42 for HTH and 92805.90 for COM.

Again, one important observation in this table is that the standard deviation which measures the degree of dispersion of the series away from the mean values is well spread. Again, all the skewness values are positive, meaning that the distribution has a long right tail and the kurtosis values for all the variables are more than3, meaning that the distribution is peaked (i.e. Leptokurtic) relative to normal.

\subsection{Unit Root Test}

This involves testing for the stationarity of the individual variables using the Augmented Dickey Fuller (ADF) test to find the existence of unit root in each of the time series. The results of the ADF test are reported in Tables 2.

Table 2: Unit Root Test Results

Augmented Dickey Fuller (ADF) Test

\begin{tabular}{lllll}
\hline Variables & Level & $1^{\text {st }}$ Difference & Status & Remarks \\
\hline LOG(UNE) & -1.714847 & -6.432602 & $\mathrm{I}(1)$ & Stationary \\
LOG(EDU) & -1.392543 & -5.074444 & $\mathrm{I}(1)$ & Stationary \\
LOG(HTH) & -0.931260 & -9.807971 & $\mathrm{I}(1)$ & Stationary \\
LOG(COM) & -1.334743 & -7.238061 & $\mathrm{I}(1)$ & Stationary \\
\hline
\end{tabular}

\begin{tabular}{ccc}
\hline Critical Values & Level & $1^{\text {st }}$ Difference \\
$1 \%$ & -3.626784 & -3.632900 \\
$5 \%$ & -2.945842 & -2.948404 \\
$10 \%$ & -2.611531 & -2.612874 \\
\hline
\end{tabular}

Source: Authors' Computation (2017)

The result of the variables in Table 2 shows that all the variables (UNE, EDU, $\mathrm{HTH}$ and $\mathrm{COM}$ ) were stationary at their $1^{\text {st }}$ difference. This is the variables are all integrated of order 1 , that is, though they are non-stationary at 
levels, they are however stationary at their first differences. Notwithstanding the non-stationarity of the variables at levels, there exists the possibility that a linear combination of the variables will be stationary. This implies existence of long run (equilibrium) relationship between them. In other words, the variables could be cointegated. The test for cointegration is performed using the Johansen procedure.

\subsection{The Co-integration Test}

The results of the test for cointegration using the Johansen procedure are presented in Table 3 below.

Table 3: Johansen Co-integration Test Results

\begin{tabular}{ccccc}
\hline \multicolumn{3}{l}{ Unrestricted Cointegration Rank Test (Trace) } & & \\
& & & \\
Hypothesized & Eigenvalue & Trace & 0.05 & Prob. $^{* *}$ \\
No. of CE(s) & & Statistic & Critical Value & \\
\hline None $^{*}$ & 0.637303 & 55.26808 & 47.85613 & 0.0086 \\
At most 1 & 0.364686 & 21.79985 & 29.79707 & 0.3098 \\
At most 2 & 0.182378 & 6.829840 & 15.49471 & 0.5975 \\
At most 3 & 0.005594 & 0.185137 & 3.841466 & 0.6670
\end{tabular}

Trace test indicates 1 cointegrating eqn(s) at the 0.05 level

${ }^{*}$ denotes rejection of the hypothesis at the 0.05 level

${ }^{* *}$ MacKinnon-Haug-Michelis (1999) p-values

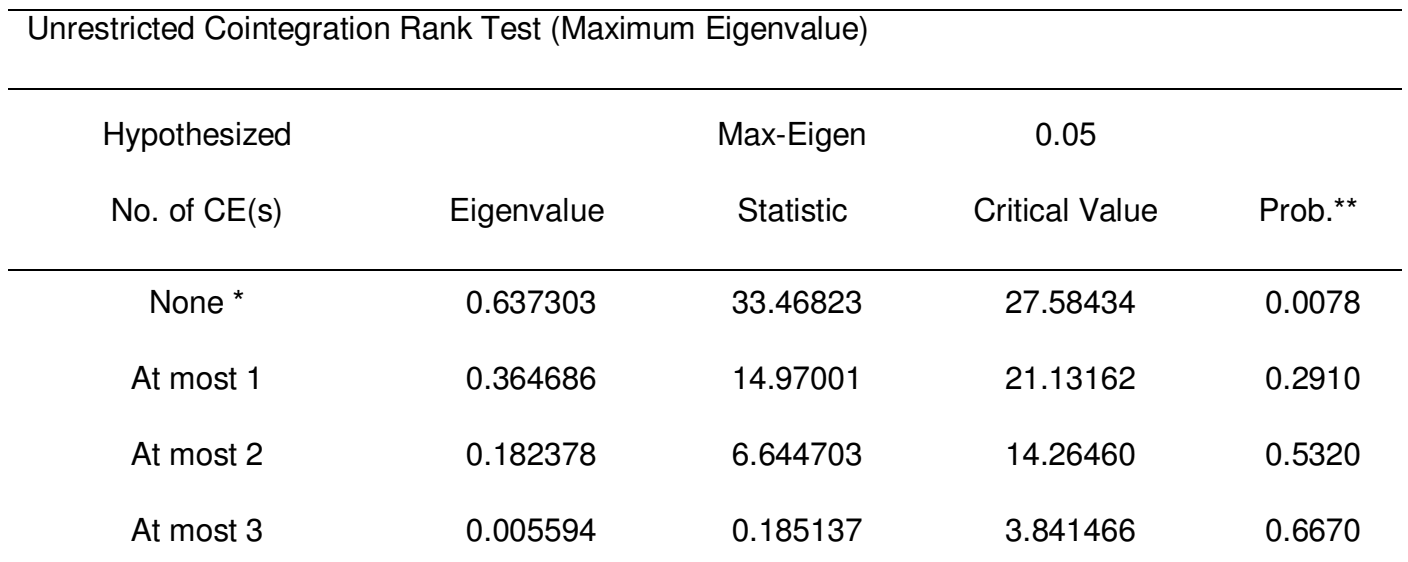

Max-eigenvalue test indicates 1 cointegrating eqn(s) at the 0.05 level

${ }^{*}$ denotes rejection of the hypothesis at the 0.05 level

${ }^{* *}$ MacKinnon-Haug-Michelis (1999) p-values

Source: Authors' Computation (2017)

The result of the co-integration is based on both the Trace Statistics and Maximum Eigenvalue. The result indicate that a one cointegrating equation for both the Trace Statistics and Maximum Eigenvalue at 5 percent level. This shows that the variables are indeed cointegrated.

\subsection{Estimation Result}


The result of estimation of the model specified using the DOLS method is presented in Table 4 below.

Table 4: DOLS Estimation Results

Dependent Variable: LOG(UNE)

Method: Dynamic Least Squares (DOLS)

Sample (adjusted): 19822013

Included observations: 32 after adjustments

Cointegrating equation deterministics: $\mathrm{C}$

Fixed leads and lags specification (lead=1, lag=1)

Long-run variance estimate (Bartlett kernel, Newey-West fixed bandwidth $=4.0000$ )

\begin{tabular}{ccccl}
\hline Variable & Coefficient & Std. Error & t-Statistic & Prob. \\
LOG(EDU) & -0.727341 & 0.204733 & -3.552633 & 0.0021 \\
LOG(HTH) & 0.660216 & 0.207750 & 3.177928 & 0.0050 \\
LOG(COM) & 0.195768 & 0.085240 & 2.296675 & 0.0332 \\
C & 1.981414 & 0.303253 & 6.533860 & 0.0000 \\
R-squared & 0.937622 & Mean dependent var & 2.270052 \\
Adjusted R-squared & 0.898226 & S.D. dependent var & 0.540272 \\
S.E. of regression & 0.172358 & Sum squared resid & 0.564438 \\
Long-run variance & 0.050437 & Durbin- Watson stat & 1.778208 \\
\hline
\end{tabular}

Source: Authors' Computation (2017

Table 4 shows that the coefficient of Government Expenditure on Education (EDU) is -0.727341 , meaning that one percent increase in Government Expenditure on Education (EDU) reduces Unemployment (that is generated employment) by about 0.73 percent. The value of the coefficient of Government Expenditure on Education (EDU) is rightly signed and is statistically significant at 5 percent level. This finding corroborates previous studies such as Abu and Usman (2010) and Osundina, Ebere and Osundina (2014).

Also, the coefficient of Government Expenditure on Health $(\mathrm{HTH})$ and Government Expenditure on Other Social and Community services (COM) are 0.660216 and 0.195768 , respectively. This finding is consistent with previous studies such as Osundina, Ebere and Osundina (2014) and Eba, Obim, Emori and Nkamare (2017). This means that one percent increase in Government Expenditure on Health (HTH) and Government Expenditure on Other Social and Community services (COM) increases unemployment (that is, reduces employment generation) by about 0.66 and 0.19 per cents respectively and are statistically significant at 5 percent level. This implies that Government Expenditure on Health (HTH) and Government Expenditure on Other Social and Community services (COM) have not generated employment in Nigeria within the period under review.

The coefficient of determination of 0.9376 indicates that 93.76 percent of the systemic variation in the dependent variable is explained by the regressors. The Durbin-Watson statistics of 1.778 indicates the absence of autocorrelation. The long run variance of 0.0504 is quite low and satisfactory. Thus, the results could be reliably deployed for policy purposes.

\section{DIAGNOSTIC TESTING}

The result of the diagnostic tests is presented in table 5 below. We conducted the Linearity test (using Ramsey 
Reset Test), Serial Correlation test (using BreuschGodfrey Serial Correlation LM Test), Heteroscedasticity test (using Breusch-Pegan-Godfrey Test), Normality test (using Jarque-Bera Statistics) and Stability test (using CUSUM \& CUSMSQ test). The study reveals that the model passes the diagnostic tests against serial correlation, functional form misspecification, heterosckedasticity and non-normal errors as presented in Table 6 below. Also, the model passes the stability test using the Cumulative Sum of Square (CUSUMSQ) that there is stability in the coefficients over the sample period as shown in figure 1 below. This is so because the plots of the CUSUMSQ remained within the critical 5 percent limit.

Table 5: Diagnostic Test Results

\begin{tabular}{|c|c|c|c|}
\hline \multicolumn{4}{|c|}{ Breusch-Godfrey Serial Correlation LM Test: } \\
\hline F-statistic & 0.118475 & Prob. $F(2,30)$ & 0.8887 \\
\hline Obs ${ }^{\star} R$-squared & 0.282111 & Prob. Chi-Square(2) & 0.8684 \\
\hline
\end{tabular}

Heteroskedasticity Test: Breusch-Pagan-Godfrey

\begin{tabular}{llll}
\hline F-statistic & 1.009687 & Prob. F(3,32) & 0.4012 \\
Obs ${ }^{\star}$ R-squared & 3.113020 & Prob. Chi-Square(3) & 0.3745 \\
Scaled explained SS & 2.019367 & Prob. Chi-Square(3) & 0.5684
\end{tabular}

Source: Authors' Computation (2017)

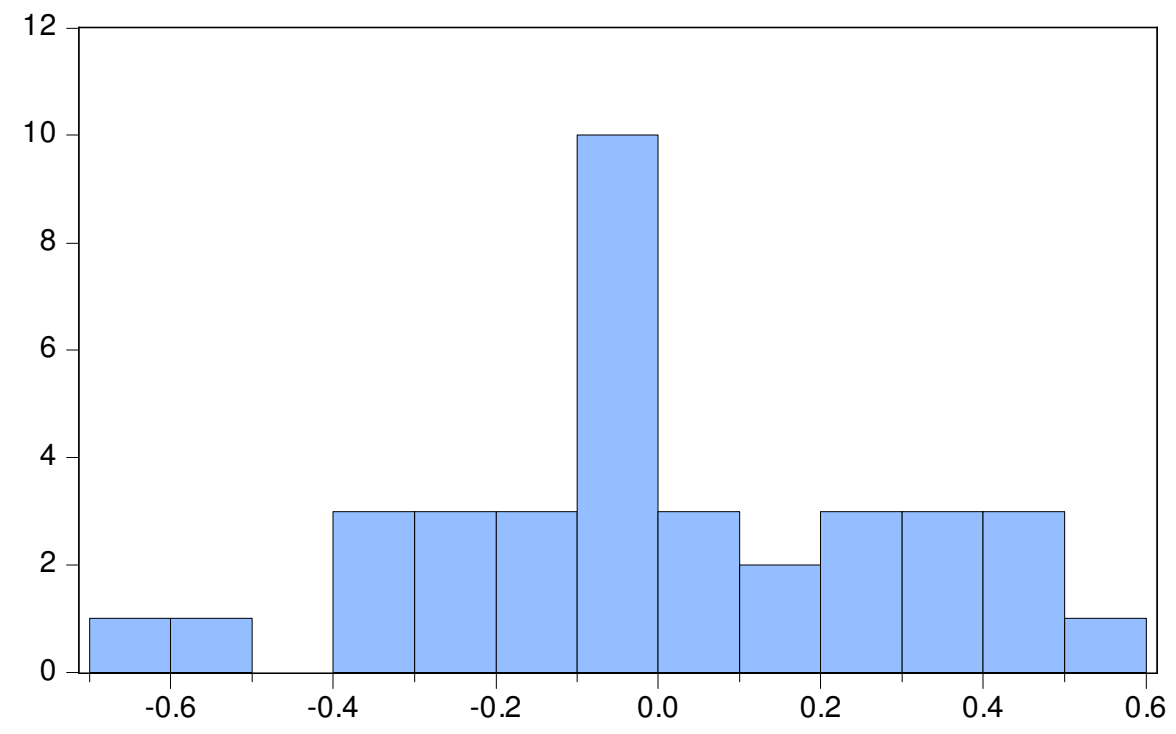

Figure 1: Jarque Bera normality test
Series: Residuals

Sample 19802016

Observations 36

Mean

$-1.15 \mathrm{e}-15$

Median

$-0.043965$

Maximum

0.540970

Minimum

$-0.658995$

Std. Dev.

0.288150

Skewness

$-0.110932$

Kurtosis

2.641982

Jarque-Bera

0.266100

Probability 


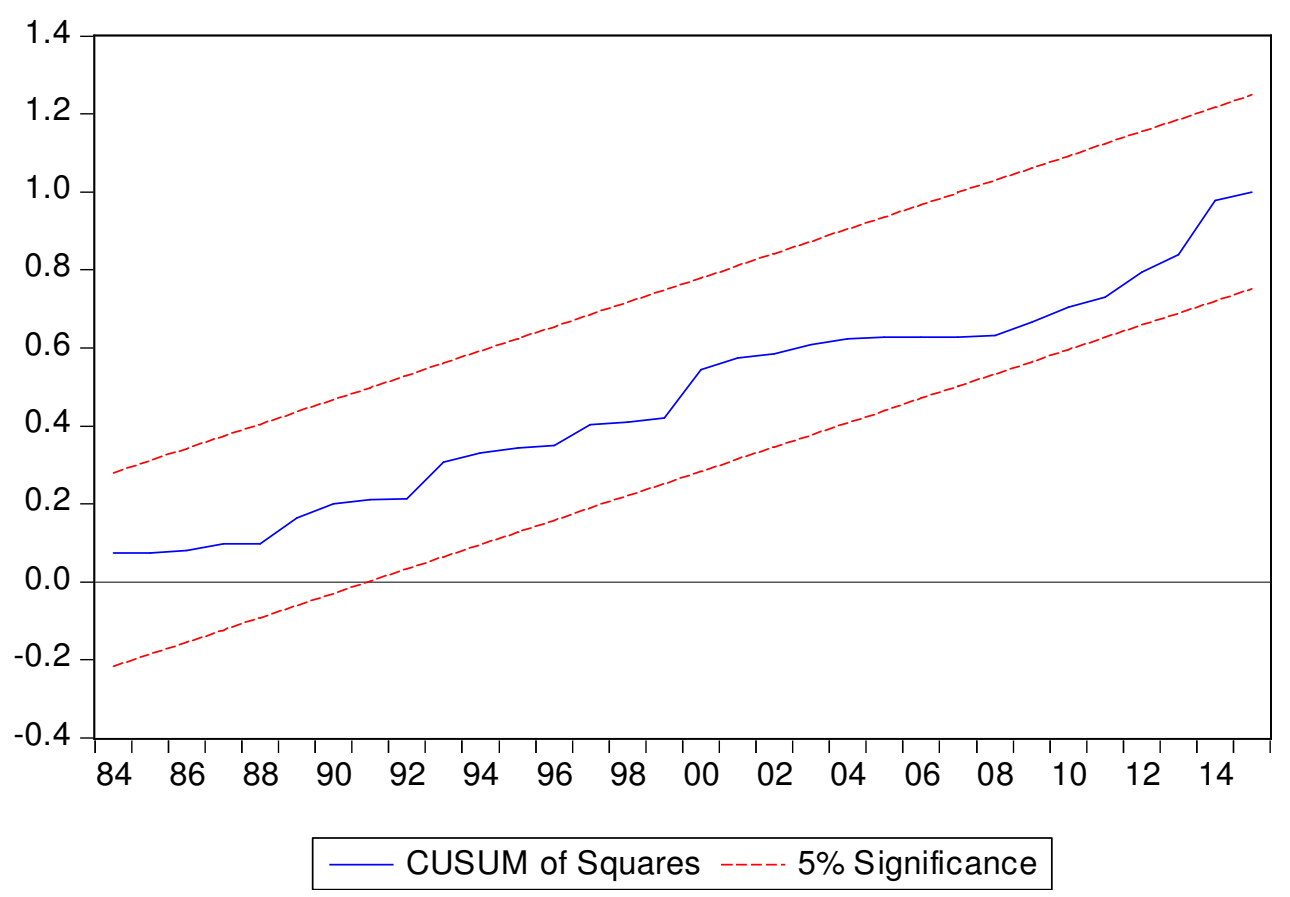

Figure 2: Cumulative Sum of Recursive Residuals

\section{CONCLUDING REMARK}

The study examines empirically the effect of public expenditure on the social sector and employment generation in Nigeria between 1980 and 2016 using the Stock-Watson Dynamic Ordinary Least Squares (DOLS) estimation technique for the analysis.

The result of the analysis showed that the value of the coefficient of Government Expenditure on Education (EDU) is rightly signed and is statistically significant while Government Expenditure on Health $(\mathrm{HTH})$ and Government Expenditure on Other Social and Community services (COM) were wrongly signed and are statistically significant at 5 percent level. This implies that Government Expenditure on Health $(\mathrm{HTH})$ and Government Expenditure on Other Social and Community services (COM) have not generated employment in Nigeria within the period under review.

Based on the findings, the study recommends that government should encourage the education and health sectors through increased funding, as well as ensuring that the resources are properly managed and used for the development of education and health services. Lastly, government should increase its funding of anti-graft or anti-corruption agencies like the Economic and Financial Crime Commission (EFCC), and the Independent Corrupt Practices Commission (ICPC) in order to arrest and penalize those who divert and embezzle public funds.

\section{REFERENCES}

Abu, N., \& Usman, A. (2010). Government expenditure and economic growth in Nigeria, 1970-2008: A Disaggregated Analysis. Business and Economics Journal, 2-10: BEJ-4

Adebayo, F. A., \& Ayegbusi, E. T. (2017). Public-private partnership as mechanism for employment creation in Nigeria. Journal of Education and Practice, 8(9), 178-185.

Adediran, I. A. (2014). Public investment in human capital and economic growth in Nigeria: Analysis on Regime Shifts. Journal of Economics and Development Studies, 2(1), 12-26.

Agiobenebo, T. J. (2000). Public Sector Economics: Theories, Issues and Applications. Port Harcourt. Lima Computers.

Ajakaiye, O., Afeikhena, T. J., David, N., \& Olufunke, A. A. (2016). Understanding the relationship between growth and employment in Nigeria. Africa Growth Initiative development Research Unit, 1-32.

Al-Azzam, A. \& Hawdon, D. (1999). Estimating the demand for energy in Jordan: A stock-Watson Dynamic OLS Approach. Surrey energy Economics Discussion Paper 97.

Apata, T. G., Sanusi, R. A., Obaisi, A., \& Ajani, O. (2016). Exploration of public spending and agricultural growth. Comparative analysis of Nigerian and Malaysian agricultural growth (1970-2010). 5th International Conference of the African Association of Agricultural Economists, September 23-26, 2016, Addis Ababa, Ethiopia.

Babatunde, M. A., \& Adefabi, R. A. (2005). Long run between education and economic growth in Nigeria: Evidence from the Johansen's Cointegration 
Approach. Paper Presented at the Regional Conference on Education in West Africa, Constraints and Opportunities, Dakar, Senegal. Cornell University/ CREA/ Ministerade L. Education de Senegal.

Denison, B. F. (1983). Trends in American Growth: The Brookings Institution.

Eba, A. O., Obim, E. N., Emori, E. G., Nkamare, S. E. (2017). A disaggregated analysis of government expenditure on the growth of Nigeria economy (1990-2015). Research Journal of Finance and Accounting, 8(14), 116-122.

Ekpenyong, A. E., Edem, J. O., \& Ndiyo, N. A. (2016). Public private investment and tourism development in Nigeria: A Case Study of Cross River State. Landmark Research Journals of Business Management and Economics (LRJBME), 1(1), 001008.

Elekwa, P., Aniebo, C., \& Ogu, C. (2016). Does foreign portfolio investment affect employment growth in Nigeria? Journal of Economics and Sustainable Development, 7(12), 81-84.

Fagerlind, A. \& Saha, L. (1997). Education and National Developments, Reed Educational and Professional Publishing Ltd, New Delhi.

Fasanya, I. O. \& Adegbemi, B. O. (2012). Informal sector and employment generation in Nigeria: An Error Correction Model. Research on Humanities and Social Sciences Vol2, No.7, 2012.

Harbison, F. H. (1973). Human Resource as the wealth of Nations: New York, Oxford University Press.

Kareem, R. O. (2015). Employment level and economic growth of Nigeria. Journal of Sustainable Development Studies, 8(1), 53-70.

Lawal, N. A. \& Wahab, T. I. (2011). Education and economic growth: The Nigerian Experience, Journal of Emerging Trends in Economics and Management Sciences, 2(3), 225-231.
Mbah, S, A. \& Agu, O. C. (2013). The effectiveness of government employment policies in Nigeria. Journal of Humanities and Social Sciences. 12(3), 65-71.

Oaikhenan, H. E. \& Aigheyisi, O. S. (2015). Investment, government expenditure and unemployment in Nigeria. The Nigerian Journal of Economic and Social Studies, 57(2), 201-223.

Ogunrinola, I. O. (2010). Internal self-employment and poverty alleviation: Empirical Evidence from Motorcycle Taxi Riders in Nigeria: International Journal of Economics and Finance.

Okafor, S. O., \& Kenneth, J. (2016). Public spending for growth-induced employment: The Nigerian experience. British Journal of Economics, Management \& Trade, 12(1), 1-19.

Olayemi, S. O. (2012). Human capital investment and industrial productivity in Nigeria, International Journal of Humanities and Social Science, 2(16), 298-307.

Osundina, C. K., Ebere, C., \& Osundina, O. A. (2014). Disaggregated government spending on infrastructure and poverty reduction in Nigeria. Global Journal of Human and Social science, 14(5), 1-7.

Saima et al., (2012). An Empirical analysis of higher education and economic growth in West Virginia, Paper Presented at Agricultural \& Applied Economics Annual Meeting, August 12-14, Seattle, WA.

Sodipe, O. A. \& Ogunrinola, O. I. (2011). Employment and economic growth nexus in Nigeria. International Journal of Business and Social Sciences, 2(11), 3046.

Solow, R. M. (1957). Technical change and aggregate production function, Review of Economics and Statistics.
Cite this Article: Charles D, Nenbee SG and Krama IJ (2018). Public Investment in the Social Sector and Employment Generation in Nigeria, 1980-2016. Greener Journal of Social Sciences, 8(1): 001-011, http://doi.org/10.15580/GJSS.2018.1.122617182. 